\title{
CREATIVE AND INNOVATIVE PROBLEM SOLVING (CIPS) DALAM PEMBELAJARAN MATEMATIKA BERBASIS MNR (MATEMATIKA NALARIA REALISTIK)
}

\author{
Linda Pebriani ${ }^{1}$, Dwi Wulandari², Rahyu Setiani ${ }^{3}$, Dian S. N. Afifah ${ }^{4}$ \\ 1,3,4 Universitas Bhinneka PGRI Tulungagung \\ 2 SMK Al Khoiriyah \\ email korespondensi : lindapebriani77@gmail.com
}

\begin{abstract}
Diterima : (11-10-2020), Revisi: (30-11-2020), Diterbitkan : (24-12-2020)
\section{ABSTRAK}

Permasalahan matematika sangat beragam baik dari segi siswa, guru, metode belajar, gaya belajar, maupun pemecahan masalah. Pemecahan masalah merupakan hal yang menjadi aktivitas pokok dan metode berpikir dalam menyelesaikan masalah menjadi hal yang penting untuk dilakukan. Permasalahan matematika yang diselesaikan berdasarkan nalar dan logika sehingga memunculkan berbagai solusi pemecahan yang bervariasi disebut dengan Matematika Nalaria Realistik (MNR). MNR merupakan sebuah metode yang dapat diterapkan dalam pembelajaran, sehingga nantinya dari hasil pengerjaan siswa dapat diketahui kreativitas serta inovasi siswa dalam menyelesaikan permasalahan matematika. Kreativitas dan Inovasi dalam pemecahan masalah bisa disebut dengan Creative and Innovative Problem Solving (CIPS) yaitu sebuah proses pemecahan masalah dengan mengembangkan daya berfikir siswa yang meliputi klarifikasi masalah, pengungkapan pendapat, membangun pengetahuan, evaluasi dan pemilihan strategi, serta implementasi. Penelitian ini dilakukan guna meningkatkan kemampuan siswa dalam memecahkan berbagai permasalahan dan persoalan matematika yang selama ini dianggap sulit oleh mayoritas siswa. Berdasarkan penelitian studi literatur yang dilakukan maka dapat disimpulkan bahwa langkah-langkah MNR yang diterapkan dalam pembelajaran dapat menumbuhkan CIPS.

Katakunci: Problem Solving, Creative, Innovative, CIPS, MNR.
\end{abstract}




\begin{abstract}
Mathematical problems are very diverse in terms of students, teachers, learning methods, learning styles, and problem solving. Problem solving is the main activity and the method of thinking in solving problems is an important thing to do. Mathematical problems that are solved based on reason and logic so that they will give rise to various kinds of various solutions are called Realistic Mathematical Reasoning (MNR). MNR is a method that can be applied in learning, so that later on the results of student work can be seen from the creativity and innovation of students in solving math problems. Creativity and innovation in problem solving can be called Creative and Innovative Problem Solving (CIPS), which is a problem-solving process by developing student thinking which includes clarifying problems, expressing opinions, building knowledge, evaluating and selecting strategies, and implementation. This research was conducted in order to improve students' abilities in solving various mathematical problems and problems that have been considered difficult by the majority of students. Based on the literature study conducted, it can be concluded that the MNR steps applied in learning can grow CIPS.
\end{abstract}

Key words: Problem Solving, Creative, Innovative, CIPS, MNR.

\title{
Pendahuluan
}

Mata pelajaran matematika sebagai salah satu bidang ilmu dasar memiliki peranan penting dalam pengembangan ilmu pengetahuan dan teknologi (Bey \& Asriani, 2013). Matematika adalah disiplin ilmu yang telah dipelajari semenjak pendidikan dasar dan membantu perkembangan disiplin ilmu lain seperti fisika, kimia, biologi, ekonomi, dan lainnya (Anggoro, 2015). "Matematika salah satu mata pelajaran penting yang memiliki tujuan umum berdasarkan NCTM yaitu: komunikasi matematis, penalaran matematis, pemecahan masalah matematis, koneksi matematis, representasi matematis" (Widodo \& Kartikasari, 2017). Sesuai dengan tujuan pembelajaran matematika di jenjang pendidikan dasar dan pendidikan menengah adalah untuk mempersiapkan peserta didik agar dalam dunia pendidikan dapat selalu berkembang secara logis, rasional, kritis, cermat, jujur, efisien dan efektif (Syazali, 2015).

Dalam pembelajaran matematika, kemampuan penalaran berperan penting baik dalam pemahaman konsep maupun pemecahan masalah (problem solving) (Agustin, 2016). "Problem solving dalam pembelajaran khususnya pembelajaran matematika bertujuan mengarahkan siswa menjadi pemecah masalah melalui melatih kemampuan berpikir yang dimulai dari memahami masalah sampai pada menarik kesimpulan terhadap hasil yang diperoleh" (Fariha, 2013). Problem solv- 
ing atau dikenal dengan pemecahan masalah merupakan hal yang tidak mudah dalam pembelajaran matematika bagi siswa ataupun dalam penerapan pendekatan problem solving bagi seorang guru (Hidayat \& Irawan, 2017). Selama pembelajaran matematika, dalam mempelajari konsep-konsep, siswa tidak terlepas dari suatu permasalahan matematis yang membutuhkan sebuah solusi (Nopitasari, 2016). Dalam menyelesaikan masalahnya siswa diharapkan mampu untuk memahami masalah tersebut, sehingga dapat membuat rencana dan proses dalam menyelesaikan masalah secara tepat (Afriansyah, 2016).

Pemecahan masalah dengan tujuan untuk memperkenalkan atau menemukan konsep matematika tertentu, hal inilah sekiranya yang menjadi fokus utama pendekatan problem solving (Santi \&Abadi, 2015). Kemampuan pemecahan masalah siswa di Indonesia masih tergolong rendah. Hal ini terbukti dari penelitian The Third International Mathematics and Science Study (TIMSS) dan Programme for International Student Assessment (PISA) mencerminkan rendahnya kemampuan pemecahan masalah matematika siswa (Ulya, 2016). Indonesia berada diurutan ke-45 dari 50 negara peserta dengan skor rata-rata 397, sedangkan skor rata-rata internasional 500. Kondisi yang tidak jauh berbeda juga terlihat dari hasil study yang dilakukan PISA 2015 lebih memprihatinkan, "berturut-turut rata-rata skor pencapaian siswa-siswi Indonesia untuk Sains, Membaca, dan Matematika berada di peringkat 62, 61, dan 63 dari 69 negara yang dievaluasi” (Ikhsan \& Fitria, 2017).

Dari penelitian yang telah dilakukan oleh peneliti terdahulu menyebutkan bahwa tingkat mahasiswa juga lemah dalam pemecahan masalah. Sebagai contoh berdasarkan hasil pengamatan terhadap mahasiswa pendidikan UNIMUS angkatan 2011/2012, sekitar 75\% lemah dalam kemampuan pemecahan masalah. Ketidakmampuan mereka dapat terlihat saat harus menjelaskan dan menyelesaikan permasalahan matematika terhadap teman sejawat di depan kelas (Purnomo \& Mawarsari, 2014). "Most of students today think that math is a subject very difficult and complicated, making them reluctant to learn it" (Pardimin \& Widodo, 2016). Pardimin dan Widodo menyebutkan bahwa mayoritas siswa berpikir bahwa matematika adalah pelajaran yang sangat sulit dan rumit, sehingga membuat siswa enggan untuk mempelajarinya.

Penyelesaian permasalahan matematika memerlukan adanya sebuah kreativitas, sehingga siswa akan dapat menyelesaikan permasalahan dengan beragam kemungkinan. Kemampuan berpikir untuk menemukan banyak kemungkinan ja- 
waban pada suatu masalah, dimana penekanannya pada kuantitas, ketepatgunaan, dan keberagaman jawaban disebut sebagai kreativitas (berpikir kreatif atau divergen) (Eftafiyana, dkk., 2018). "Pengertian kreativitas terbagi dalam empat dimensi, yaitu: (1) person, (2) process, (3) product, dan (4) press". Dalam pengertian dimensi seseorang adalah seseorang yang menghasilkan prestasi kreatif ditentukan oleh bakat dan afektif, bakat yang meliputi kelancaran, kelenturan, keluwesan, dan originalitas sedangkan afektif meliputi kepercayaan diri, keuletan, dan kemandirian (Afriansyah, 2016).

Berkaitan dengan kreativitas ini metode Matematika Nalaria Realistik dapat menjadi salah satu pilihan yang digunakan dalam pembelajaran. MNR merupakan suatu terobosan baru dalam pembelajaran matematika. MNR lebih menekankan pada penggunaan nalar dalam memahami matematika (Afifah, 2015). Dengan pembelajaran Matematika Nalaria Realistik (MNR), siswa akan diajarkan menganalisis suatu masalah, menarik suatu kesimpulan serta menyelesaikan masalah dengan menggunakan suatu metode-metode dalam pemecahan masalah yang berlogika (Putra \& Amalia, 2019). Langkah-langkah MNR yang diterapkan dalam pembelajaran matematika mampu menumbuhkan kreativitas dan inovasi siswa dalam menyelesaikan masalah atau yang bisa disebut dengan Creative and Innovative Problem Solving (CIPS) yaitu sebuah proses pemecahan masalah dengan mengembangkan daya berfikir siswa yang meliputi klarifikasi masalah, pengungkapan pendapat, membangun pengetahuan, evaluasi dan pemilihan strategi, serta implementasi. Kemampuan bernalar ini nantinya akan menjadikan siswa memiliki kreativitas dan inovasi dalam menyelesaikan berbagai permasalahan matematika, sehingga pelajaran matematika menjadi lebih mudah dan menyenagkan bagi siswa.

\section{Metode Penelitian}

Metode penelitian yang digunakan adalah studi literatur mengenai metode matematika nalaria realistik dan CIPS. Data tersebut dikumpulkan melalui buku-buku dan jurnal-jurnal yang terkait, kemudian dibaca dan dikaji. Setelah data terkumpul, dilakukan pengujian dengan membandingkan data-data yang telah ditemukan. Teknik analisis data dilakukan secara kualitatif dengan mengambil serta mengutip pendapat-pendapat yang sesuai. Penggunaaan berbagai literatur 
yang relevan, untuk menghasilkan data-data yang diperlukan sesuai dengan tujuan dari penelitian.

\section{Hasil dan Pembahasan}

\section{Problem Solving}

"Problem atau masalah adalah satu hal yang mungkin tidak dapat dilepaskan dari kehidupan manusia sehari-hari" (Patnani, 2013). Sesuatu dikatakan masalah jika "masalah tersebut dinyatakan dalam suatu bentuk tertentu tetapi dapat diubah ke dalam bentuk yang lain, selanjutnya ia tidak memiliki prosedur yang langsung dapat dipakai untuk menyelesaikannya" (Kurniawan, 2016). Instruksi problem solving memiliki peluang yang besar dalam mengembangkan kemampuan/ bakat matematika siswa (Hodiyanto, 2017). "Problem solving mencakup tiga tahap kegiatan yaitu tahap pertama penyajian masalah dimana siswa dihadapkan pada suatu tujuan yang harus dicapai melalui beberapa kesulitan/hambatan, tahap kedua kegiatan ke arah pemecahan dimana siswa akan mengalami proses mental atau simbolik, seperti mengamati, mengingat kembali hal-hal yang telah lampau, mengemukakan pertanyaan, mengungkapkan gagasan dan tahap ke tiga pemecahan yaitu siswa mungkin berhasil atau tidak berhasil mencapai tujuannya" (Suhendri, 2008).

"Problem solving adalah belajar memecahkan masalah, pada tingkat ini peserta didik belajar merumuskan memecahkan masalah, memberikan respons terhadap rangsangan yang menggambarkan atau membangkitkan situasi problematik, yang menggunakan berbagai kaidah yang telah dikuasainya" (Agustin, 2016). "In mathematics, problem-solving skills have an important role, namely as an initial capability for students in formulating the concept and capital success for students in solving mathematical problems. In addition, students can develop an idea or ideas they have" (Widodo, 2017). Hal ini mengandung makna bahwa di dalam matematika kemampuan pemecahan masalah memiliki peran yang penting yaitu sebagai kemampuan siswa dalam merumuskan konsep dan mencapai keberhasilan dalam menyelesaikan masalah matematika, terlebih lagi siswa dapat mengembangkan ide-ide yang mereka miliki. Siswa dikatakan mampu memecahkan masalah matematika jika mereka dapat memahami, memilih strategi yang tepat, kemudian menerapkannya dalam penyelesaian masalah (Zulyadaini, 2017).

\section{Creative Problem Solving}


Kemampuan berpikir seseorang memiliki tingkatan sesuai dengan karya yang dihasilkan oleh orang itu. Begitu juga dengan kreativitas seseorang, oleh karena itu digunakan tingkatan kreativitas sebagai perjenjangan yang hierarkis mengenai kreativitas siswa (Sari, Nofrianto, \& Amri, 2017). Creative Problem Solving (CPS) berhasil meningkatkan kemampuan siswa baik dari segi kognitif maupun afektif (Effendi \& Fatimah, 2019). Siswa yang memiliki kreatifitas dalam menyelesaikan masalah akan dapat melakukan keterampilan memecahkan masalah untuk memilih dan mengembangkan tanggapannya. Tidak hanya dengan cara menghafal tanpa dipikir, keterampilan memecahkan masalah dapat memperluas proses berpikir (Turmuzi, dkk., 2018).

Creative Problem Solving terdiri dari Problem Solving yang merupakan bagian dari pemikiran analitis dan kreativitas siswa. Untuk dapat meningkatkan keterampilan dan kreativitas siswa dalam pembelajaran, guru hendaknya merangsang siswa dalam memecahkan masalah (Novitasari, 2015). Kelebihan Creative Problem Solving yaitu "melatih siswa untuk mendesain suatu penemuan, berpikir, dan bertindak kreatif, siswa dapat memecahkan masalah yang dihadapi secara realistis; serta mengembangkan kemampuan berpikir kreatif siswa" (Muhammad, Septian, \& Sofa, 2018). "CPS merangsang anak agar berpikir kreatif yang memiliki tiga komponen yaitu memiliki keahlian, keterampilan berpikir kreatif, dan memiliki motivasi untuk menyelesaikan suatu permasalahan" (Putra, 2018).

Pemecahan masalah berdasarkan kreatifitas (Creative Problem Solving) merupakan keterampilan berpikir kreatif dalam pemecahan masalah siswa. CPS didasarkan pada peningkatan keterampilan berpikir asli (originality) baik dalam proses menemukan fakta (fact finding), menemukan masalah (problem finding), menemukan ide (idea finding), atau menemukan solusi (solution finding) (Busyairi \& Sinaga, 2015). CPS melatih siswa untuk berpikir kreatif dalam memecahkan masalah sehingga kemampuan berpikir kreatif siswa meningkat (Rolia, Rosmaiyadi, \& Husna, 2017).

\section{Innovative Problem Solving}

Inovasi pembelajaran matematika dilakukan dengan cara memilih metode pembelajaran yang sesuai dengan materi dan karakteristik siswa dan dapat membangun karakter siswa sehingga dapat meningkatkan motivasi siswa dalam belajar matematika (Wardono \& Kurniasih, 2015). Rogers dan Shoemaker (Abdullah, 2013) mengartikan inovasi sebagai "ide-ide baru, praktek-praktek baru, atau objek-objek 
yang dapat dirasakan sebagai sesuatu yang baru oleh individu atau peserta didik". Pengertian baru disini mengandung makna bukan sekadar baru diketahui oleh pikiran (cognitive), melainkan juga baru karena belum dapat diterima secara luas oleh seluruh peserta didik dalam arti sikap (attitude) dan juga baru dalam pengertian belum diterima dan diterapkan oleh peserta didik. Sedangkan menurut Kusmana (2010) "inovasi adalah suatu hasil penciptaan sesuatu yang dianggap baru yang dimaksudkan untuk mengatasi masalah, baik berupa ide, barang, kejadian, metode, dan sebagainya yang dilakukan oleh seseorang atau kelompok".

Pembelajaran inovatif adalah "pembelajaran yang dikemas oleh pebelajar atas dorongan gagasan barunya yang merupakan produk dari learning how to learn untuk melakukan langkah-langkah belajar, sehingga memperoleh kemajuan hasil belajar" (Pasaribu, dkk., 2019). Pembelajaran inovatif adalah pembelajaran yang bersifat student-centered (Rahmawati, 2016). Dalam menyelesaikan permasalahan matematika diperlukan sebuah inovasi dari siswa (Innovative problem solving). Innovative problem solving adalah pemecahan masalah yang menekankan pada kemampuan siswa dalam mencari dan merangkai konsep temuan baru sesuai dengan daya cipta yang dimiliki.Kreativitas dan inovasi adalah dua hal yang berhubungan, dimana keduanya merupakan sebuah proses yang berurutan. Creativity: bringing into existence an idea that is new to you. Sedangkan "Innovation : the practical application of creative ideas". Dengan kata lain "inovasi adalah proses kelanjutan dari kreativitas" (Utama, 2017). Dari proses kreatif ini akan dibentuk sebuah inovasi sehingga akhirnya menimbulkan suatu perubahan.

\section{Creative and Innovative Problem Solving}

Creative and Innovative Problem Solving (CIPS) yaitu sebuah proses pemecahan masalah dengan mengembangkan daya berfikir siswa yang meliputi klarifikasi masalah, pengungkapan pendapat, membangun pengetahuan, evaluasi dan pemilihan strategi, serta implementasi. Ketika dihadapkan pada permasalahan atau persoalan matematika, siswa akan langsung melakukan klarifikasi masalah yaitu memahami masalah dan dapat menjelaskan maksud dari permasalahan tersebut. Kemudian mengungkapkan pendapat terkait permasalahan, memiliki ide dan pengetahuan terkait cara penyelesaian masalah, hingga memilih langkah penyelesaian yang tepat. Langkah akhir adalah penemuan jawaban yaitu menentukan tolak ukur atas kriteria pengujian jawaban, sehingga ditemukan jawaban yang diharapkan (Sagita \& Medriati, 2018). 


\section{Matematika Nalaria Realistik (MNR)}

Salah satu pembelajaran matematika yang berorientasi pada matematisasi pengalaman sehari-hari (mathematize of everyday experience) dan dapat menalarkan ilmu matematika ini adalah pembelajaran Matematika Nalaria Realistik (MNR) (Rosita, 2015). Saputra (Putra \& Amalia, 2019) berpendapat bahwa "alur pembelajaran matematika nalaria realistik terdiri dari 5 tahap yaitu 1) Pemberian Masalah Nyata, 2) Pemahaman Konsep, 3) Tahapan HOTS (High Order Thinking Skill), 4) Permainan Matematika serta 5) Aplikasi di dalam kehidupan sehari-hari”. Menurut Fachrurazi (Sholihah, 2018), Matematika Nalaria Realistik (MNR) lebih menekankan penggunaan nalar dalam memahami Matematika, dengan MNR siswa diajarkan untuk menganalisis masalah, menarik kesimpulan, dan menyelesaikan masalah dengan berbagai metode pemecahan masalah yang berlogika. Dalam MNR siswa tidak hanya sekedar bisa menyelesaikan soal, namun siswa juga disiapkan untuk berkompetisi (Rinata \& Mariana, 2019).

Ciri khas Matematika Nalaria Realistik adalah : (1) menekankan penggunaan penalaran dalam memahami matematika; dan (2) meningkatkan daya nalar dan keterampilan memecahkan masalah, khususnya dalam kehidupan sehari-hari (Kusyatin, 2019). Sedangkan "manfaat belajar Matematika Nalaria Realistik yaitu menjadikan siswa : (1) lebih mudah memahami matematika; (2) terlatih penalarannya ketika belajar matematika; (3) lebih mudah memahami pelajaran lain karena nalarnya terasah; (4) siap menghadapi berbagai kompetisi matematika; serta (5) untuk berpikir sistematis dan mudah dipahami” (Kusyatin, 2019).

\section{Proses Matematika Nalaria Realistik}

Proses Matematika Nalaria Realistik meliputi pemberian masalah nyata, pemahaman konsep, penalaran dan komunikasi, pemecahan masalah, aplikasi dalam kehidupan, eksplorasi matematika dan permainan matematika.

1. Pemberian masalah nyata

Dalam MNR siswa diberikan masalah nyata terlebih dahulu pada saat memulai pelajaran agar siswa tertarik untuk mengikuti materi tersebut karena terlibat dan merasa berkepentingan untuk mempelajarinya. Masalah nyata sebaiknya sesuai dengan pengetahuan yang dimiliki dan cara berpikir anak (Rosita, 2015).

2. Pemahaman konsep 
Konsep matematika diberikan dengan melibatkan otak kiri dan kanan. Konsep matematika diajarkan tidak hanya menggunakan simbol-simbol matematika tetapi juga menggunakan gambar atau peraga matematika atau benda-benda yang ada di sekitar kita. Setiap pokok bahasan mempunyai teknik pengajaran yang berbeda, oleh karena itu faktor guru menjadi sangat penting dalam penyampaian konsep-konsep matematika tersebut.

3. Penalaran dan komunikasi

Penalaran dan komunikasi ditujukan untuk melatih penalaran siswa dan melatih kemampuan siswa dalam mengkomunikasikan ide dan gagasannya. Soal yang disajikan masih dalam lingkup materi yang sedang diajarkan. Hal ini dilakukan untuk membiasakan siswa untuk berpikir sistematis dan mudah dipahami (Afifah, 2015).

4. Pemecahan masalah

Pemecahan masalah dilakukan dengan menyajikan soal yang merupakan gabungan berbagai konsep matematika yang sebelumnya sudah dipelajari. Proses tersebut untuk melatih keterampilan dalam memecahkan masalah dengan merekonstruksi materi yang sudah dipelajati sebelumnya, meningkatkan daya nalar siswa, dan meningkatkan kemampuan untuk menerima pengetahuan baru (Rinata \& Mariana, 2019).

5. Aplikasi dalam kehidupan

Aplikasi dalam kehidupan dilakukan dengan menerapkan konsep matematika dalam kehidupan sehari-hari dengan tujuan agar Siswa dapat mengetahui tujuan mempelajari suatu konsep matematika dan memancing ketertarikan siswa untuk mempelajari materi berikutnya.

6. Eksplorasi matematika

Eksplorasi matematika dilakukan untuk melatih keterampilan psikomotorik serta melatih mental siswa untuk berpikir kreatif dan patang menyerah

7. Permainan matematika

Permainan matematika dilakukan untuk membuat siswa senang belajar matematika serta mempermahir pemahaman konsep yang sudah dipahami.

Kreativitas dan inovasi siswa dalam menyelesaikan masalah berbasis MNR ini tampak pada cara siswa dalam memberikan jawaban. Beberapa contoh soal pada bab bilangan yang menumbuhkan kreativitas dan inovasi tersebut antara lain: 
1. Berikan tanda operasi hitung $(+,-, \mathrm{x}, \mathrm{:})$ diantara 4 buah angka berikut supaya mendapat hasil seperti yang diminta!

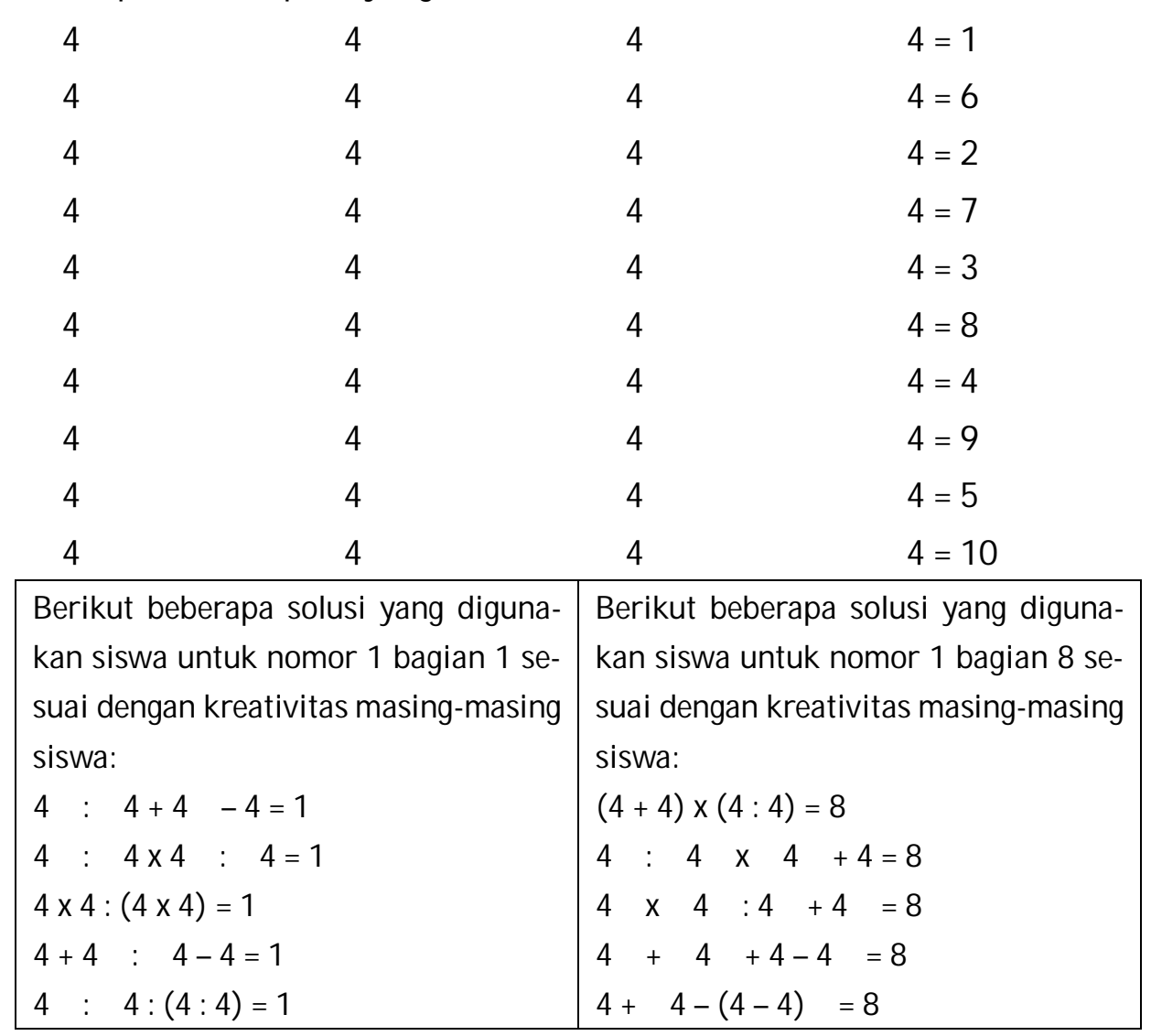

2. Jika Andi hanya boleh bergerak ke arah utara atau timur, maka ada berapa carakah agar Andi bisa mencapai Toko B dari Toko A?

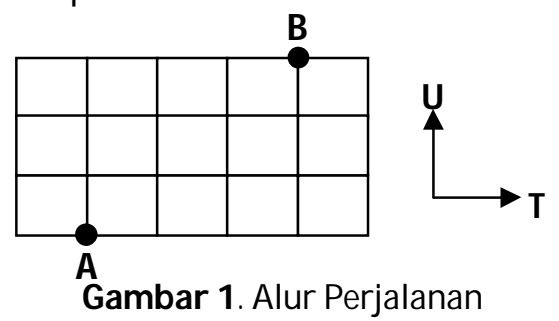

Solusi untuk soal nomor 2 juga bervariasi. Ada yang menggambarkan lintasannya satu persatu ada pula yang menghitung jumlah di setiap titik pertemuannya. Soal ini juga menumbuhkan kreativitas siswa. Siswa juga memiliki inovasi saat memecahkan permasalahan tersebut. Hal ini dapat dilihat dari kemampuan siswa dalam membangun pengetahuan untuk menyelesaikan masalah baru yang diberikan padanya. 
Beberapa soal lain yang menumbuhkan kreativitas siswa dalam penyelesaiannya dengan kata lain siswa memiliki beragam ide baru serta menuangkan ide tersebut dalam sebuah langkah untuk menyelesaikannya, selain itu siswa mampu berinovasi membentuk pengetahuan baru dari permasalahan matematika yang belum ditemui sebelumnya atau merupakan pengembangan dari materi yang telah dipelajari sehingga masih terasa baru bagi siswa antara lain:

1. $12345678 \times 99999999$

2. $\frac{1+2+3+\cdots+9+10+9+\cdots+3+2+1}{22 \times 33+11 \times 44} \times 121$

3. $\frac{20202019^{2}}{20202018^{2} 20202020^{2}-2}$

4. Manakah dari bilangan-bilangan berikut yang paling besar?
a. $3^{666}$
c. $5^{444}$
e. $7^{222}$
b. $4^{555}$
d. $6^{333}$

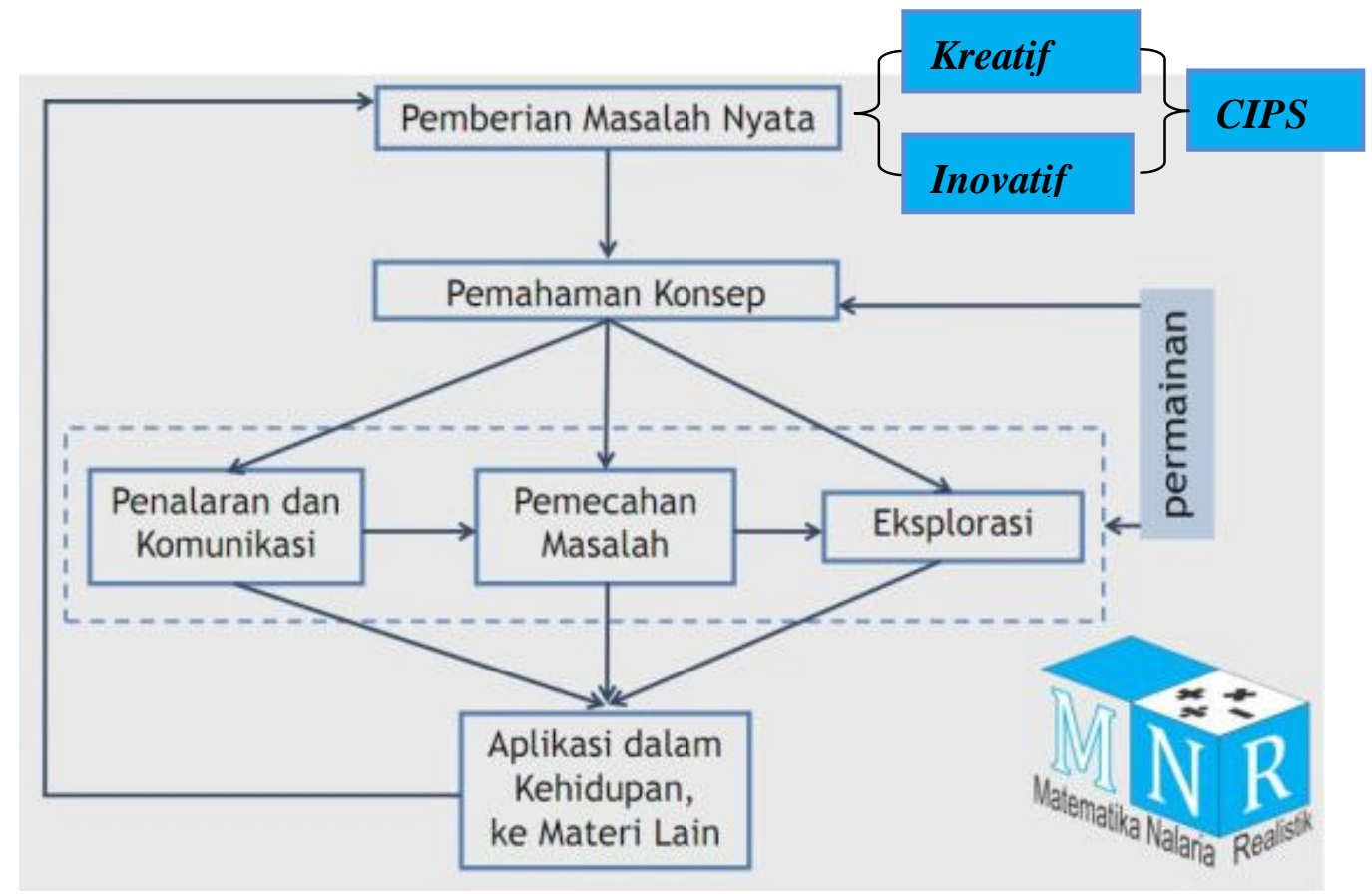

Gambar 2. Alur Penyelesaian Masalah MNR yang Menumbuhkan CIPS

Aplikasi MNR dalam pembelajaran langkah pertamanya yaitu siswa diberikan masalah nyata yang berkaitan dengan kehidupan sehari-hari, selanjutnya siswa diberikan pemahaman konsep berkaitan dengan materi yang telah dibahas dengan demikian dapat mendorong siswa untuk selalu mengingat materi apa yang telah 
dipelajari, langkah berikutnya siswa diberikan soal untuk mengasah penalaran dan komunikasi, kemudian masuk pada tahap pemecahan masalah yaitu siswa dihadapkan pada sebuah soal yang berupa soal cerita terkait materi yang diajarkan, langkah terakhir yaitu eksplorasi (mengeksplor pengetahuan dari materi yang dipelajari) yang kemudian dapat diaplikasikan dalam kehidupan dan juga diaplikasikan ke materi lain. Langkah-langkah tersebut dapat memunculkan kreativitas siswa dalam menyelesaikan soal-soal yang diberikan serta dapat membangun pengetahuan siswa dalam penyelesaiannya (menumbuhkan inovasi siswa dalam menyelesaikan masalah).

Proses matematika nalaria realistik yang telah diterapkan dan diakhiri dengan pemberian soal bagi siswa memberikan kebebasan bagi siswa dalam menentukan berbagai langkah pemecahan masalah sehingga kreativitas akan muncul saat pengerjaan soal-soal matematika, dari proses kreatif ini muncul penciptaan pengetahuan dalam melakukan penemuan baru yang berbeda dan/atau modifikasi dari yang sudah ada (Utama, 2017).

\section{Kesimpulan}

Metode Matematika Nalaria Realistik mampu meningkatkan kreativitas siswa dalam menyelesaikan masalah matematika serta mampu membangun pola berpikir siswa dalam menyelesaikan masalah juga menjadikan siswa memiliki inovasi dalam penyelesaiannya. Dengan Matematika Nalaria Realistik siswa mampu membangun sendiri langkah-langkah yang sesuai dalam menyelesaikan suatu persoalan berdasarkan ide dan gagasan yang dimiliki. Penggunaan Matematika Nalaria Realistik yang menggunakan tipe soal penalaran dengan langkah-langkah pemberian masalah nyata, pemahaman konsep, penalaran dan komunikasi, pemecahan masalah, aplikasi dalam kehidupan, eksplorasi matematika, serta permainan matematika ini mampu menumbuhkan Creative And Innovative Problem Solving (CIPS) siswa pada pembelajaran matematika. CIPS ini berkembang pada salah satu langkah pada matematika nalaria realistik yaitu tahap pemecahan masalah. Pada langkah ke empat dalam MNR yaitu langkah pemecahan masalah, CIPS dan daya nalar siswa tumbuh dan berkembang bersamaaan. 


\section{Daftar Pustaka}

Afifah. (2015). Efektivitas Metode Pembelajaran Matematika Nalaria Realistik (MNR) Terhadap Kemampuan Berpikir Kritis dan Self Efficacy Matematis Siswa SMP Negeri 1 Banguntapan.

Afriansyah, E. A. (2016). Investigasi Kemampuan Problem Solving dan Problem Posing Matematis Mahasiswa Via Pendekatan Realistic. Jurnal Mosharafa 5(3), 269-280.

Agustin, R. D. (2016). Kemampuan Penalaran Matematika Mahasiswa Melalui Pendekatan Problem Solving. Jurnal Pedagogia, 5(2), 179-188.

Anggoro, B. S. (2015). Pengembangan Modul Matematika Dengan Strategi Problem Solving untuk Mengukur Tingkat Kemampuan Berpikir Kreatif Matematis Siswa. Jurnal Pendidikan Matematika, 6(2), 121-129.

Bey, A., \& Asriani. (2013). Penerapan Pembelajaran Problem Solving untuk Meningkatkan Aktivitas dan Hasil Belajar Matematika pada Materi SPLDV.Jurnal Pendidikan Matematika, 4(2), 224-239.

Busyairi, A., \& Sinaga, P. (2015). Strategi Pembelajaran Creative Problem Solving (CPS) Berbasis Eksperimen Untuk Meningkatkan Kemampuan Kognitif dan Keterampilan Berfikir Kreatif. Jurnal Pengajaran MIPA, 20(2), 133-143.

Effendi, A., \& Fatimah, A. T. (2019). Implementasi Model Pembelajaran Creative Problem Solving Untuk Siswa Kelas Awal Sekolah Menengah Kejuruan. 4(2), 89-98.

Eftafiyana, S., Nurjanah, S. A., Armania, M., Sugandi, A. I., \& Fitriani, N. (2018). Hubungan antara kemampuan berpikir kreatif matematis dan motivasi belajar siswa smp yang menggunakan pendekatan creative problem solving. Jurnal Teori Dan Riset Matematika, 2(2), 85-92.

Fariha, M. (2013). Kemampuan Berpikir Kritis Matematis dan Kecemasan Matematika Dalam Pembelajaran Dengan Pendekatan Problem Solving. Jurnal Peluang, 1(2), 43-50.

Hidayat, A., \& Irawan, I. (2017). Pengembangan LKS Berbasis RME Dengan Pendekatan Problem Solving Untuk Memfasilitasi Kemampuan Pemecahan Masalah Matematis Siswa. Jurnal Cendekia, Jurnal Pendidikan Matematika, 1(2), 51-63.

Hodiyanto, H. (2017). Pengaruh Model Pembelajaran Problem Solving Terhadap Kemampuan Komunikasi Matematis Ditinjau dari Gender. Jurnal Riset Pendidikan Matematika, 4(2), 219-228.

Ikhsan, M., Munzir, S., \& Fitria, L. (2017). Kemampuan Berpikir Kritis dan Metakognisi Siswa Dalam Menyelesaikan Masalah Matematika Melalui Pendekatan Problem Solving. Jurnal Pendidikan Matematika FKIP Univ. 
Muhammadiyah Metro, 6(2), 234-245.

Kurniawan, H. (2016). Efektifitas Pembelajaran Problem Solving Terhadap Keterampilan Berpikir Kritis Matematis. Prosiding Seminar Matematika Dan Pendidikan Matematika, 47-56.

Kusyatin, T. (2019). Efektivitas Metode Pembelajaran Matematika Nalaria Realistik (MNR) Terhadap Kemampuan Pemecahan Masalah dan Motivasi Belajar Siswa Kelas VIII SMP Negeri 1 Banguntapan. 13-52.

Muhammad, G. M., Septian, A., \& Sofa, M. I. (2018). Penggunaan Model Pembelajaran Creative Problem Solving Untuk Meningkatkan Kemampuan Pemecahan Masalah Matematis Siswa. Jurnal "Mosharafa" Pendidikan Matematika, 7(3), 315-326.

Nopitasari, D. (2016). Pengaruh Model Pembelajaran Creative Problem Solving (CPS) Terhadap Kemampuan Penalaran Adaptif Matematis Siswa. Jurnal Matematika Dan Pendidikan Matematika, 1(2), 103-112.

Novitasari, D. (2015). Penerapan Pendekatan Pembelajaran Creative Problem Solving (CPS) Sebagai Upaya Meningkatkan Kemampuan Berpikir Matematis Siswa. Jurnal Pendidikan Matematika \& Matematika, 1(1), 43-56.

Nur Santi, W., \& Maman Abadi, A. (2015). Keefektifan Pendekatan Problem Solving dan Problem Posing Dengan Setting Kooperatif Dalam Pembelajaran Matematika. Jurnal Riset Pendidikan Matematika, 2(1), 121-134.

Pardimin, \& Widodo, S. A. (2016). Increasing Skills of Student in Junior High School to Problem Solving in Geometry with Guided. Jurnal of Education and Learning, 10(4), 390-395.

Pasaribu, F. T., Sofnidar, Iriani, D., Rohati, \& Ramalisa, Y. (2019). Pelatihan Merancang Pembelajaran Matematika Yang Inovatif. Jurnal Pengabdian Kepada Masyarakat, 2(1), 60-66.

Patnani, M. (2013). Upaya Meningkatkan Kemampuan Problem Solving Pada Mahasiswa. Jurnal Psikogenesis, 1(2), 130-142.

Purnomo, E. A., \& Mawarsari, V. D. (2014). Peningkatan Kemampuan Pemecahan Masalah Melalui Model Pembelajaran Ideal Problem Solving Berbasis Project Based Learning. 1(1), 24-31.

Putra, E. D., \& Amalia, R. (2019). Deskripsi Kemampuan Komunikasi Matematis Siswa Dalam Pembelajaran Matematika Nalaria Realistik. Jurnal Dimensi Pendidikan Dan Pembelajaran, 7(2), 61-73.

Putra, Y. P. (2018). Penggunaan Model Pembelajaran Creative Problem Solving Untuk Meningkatkan Kemampuan Berpikir Kreatif dan Motivasi Belajar Matematika Siswa. Jurnal Penelitian Pendidikan Dan Pengajaran Matematika, 4(2), 73-80.

Rahmawati, N. D. (2016). Model Pembelajaran Inovatif Matematika Pada Mahasiswa. Jurnal E-DuMath, 2(2), 179-184. 
Rinata, M. V, \& Mariana, N. (2019). Penerapan Metode Pembelajaran Matematika Nalaria Realistik di Klinik Pendidikan MIPA Cabang Surabaya. JPGSD, 7(1), 2525-2538.

Rolia, Rosmaiyadi, \& Husna, N. (2017). Pengaruh Model Pembelajaran Creative Problem Solving Terhadap Kemampuan Berpikir Kreatif Siswa Pada Materi Program Linier Kelas XI SMK. 8(2).

Rosita, V. Y. (2015). Pengaruh Penggunaan Buku Ajar Matematika Nalaria Realistik (MNR) dalam Pembelajaran Terhadap Prestasi Belajar Siswa SD Muhammadiyah 1 Krian-Sidoarjo.

Sagita, I., \& Medriati, R. (2018). Penerapan Creative Problem Solving Model untuk Meningkatkan Kemampuan Pemecahan Masalah Fisika Siswa Kelas XI MIA 4 MAN 2 Kota Bengkulu. Jurnal Kumparan Fisika, 1(3), 1-6.

Sari, I. P., Nofrianto, A., \& Amri, M. A. (2017). Creative Problem Solving: Bagaimana Pengaruhnya Terhadap Kreativitas Siswa? Jurnal Elemen, 3(1), 87-96.

Sholihah, U. (2018). Penggunaan Strategi Matematika Nalaria Realistik (MNR) dengan Media Macromedia Flash pada Pembelajaran Bangun Ruang Ditinjau dari Hasil Belajar Siswa Kelas V SD Muhammadiyah 16 Surakarta.

Suhendri, H. (2008). Pengaruh Metode Pembelajaran Problem Solving Terhadap Hasil Belajar Matematika Ditinjau Dari Kemandirian Belajar. Jurnal Formatif, $3(2), 105-114$.

Syazali, M. (2015). Pengaruh Model Pembelajaran Creative Problem Solving Berbantuan Maple II Terhadap Kemampuan Pemecahan Masalah Matematis. Jurnal Pendidikan Matematika, 6(1), 91-98.

Turmuzi, M., Sripatmi, Azmi, S., \& Hikmah, N. (2018). Penerapan Model Pembelajaran Creative Problem Solving (CPS) Untuk Meningkatkan Kemampuan Pemecahan Masalah Mahasiswa Pendidikan Matematika. J. Pijar MIPA, 13(1), 45-50. https:/ / doi.org/ 10.29303/jpm.

Ulya, H. (2016). Profil Kemampuan Pemecahan Masalah Siswa Bermotivasi Belajar Tinggi Berdasarkan Ideal Problem Solving. Jurnal Konseling GUSJIGANG, 2(1), 90-96.

Utama, P. (2017). Berpikir Kreatif dan Inovasi. (024), 1- 73.

Wardono, \& Kurniasih, A. W. (2015). Peningkatan Literasi Matematika Mahasiswa Melalui Pembelajaran Inovatif Realistik E-Learning Edmodo Bermuatan Karakter Cerdas Kreatif Mandiri. Jurnal Matematika Kreatif-Inovatif, 6(1), 93-100.

Widodo, S. A. (2017). Development Of Teaching Materials Algebraic Equation To Improve Problem Solving. Jurnal of Mathematics Education, 6(1), 59-68. https:/ / doi.org/ 10.22460/ infinity.v6i1.239

Widodo, S., \& Kartikasari. (2017). Pembelajaran Pemecahan Masalah Matematis 
Siswa Sekolah Dasar Dengan Model Creative Problem Solving. Jurnal PRISMA Universitas Suryakancana, 6(1).

Zulyadaini. (2017). Pengaruh Model Pembelajaran Problem Solving Terhadap Kemampuan Pemecahan Masalah Matematis Siswa di SMA. Jurnal Ilmiah Dikdaya, 83-93. 